\title{
Common sense politics: religion and belonging in French public space
}

\author{
Michelle D. Weitzel ${ }^{1}$
}

Accepted: 24 September 2020 / Published online: 3 November 2020

(c) The Author(s) 2020

\begin{abstract}
Public "common sense" should be conceptualized as an important force structuring the politics of belonging. Homing in on the embodied and sensory aspects of common, taken-for-granted knowledge and the habits of perception that inform it, this article demonstrates how culturally entrained listening practices structure rights to the city and the exercise of citizenship. By tuning into the significance of ambient religious sound, it offers an empirical, ethnographic investigation into how common sense, in dialogue with constitutional and municipal law, shapes practices of citizenship and participation in French public space. The article argues that common sense deriving from perception and interpretation of public sound among majority French represents a stubborn obstacle to French Muslims' exercise of full citizenship; indeed, it enacts a kind of violence that locks French Muslims out of agentive citizenry, rendering them objects to be muted at will, not fellow citizens to be heard.
\end{abstract}

Keywords Citizenship $\cdot$ France $\cdot$ Islam $\cdot$ Laïcité $\cdot$ Public space $\cdot$ Senses

“Comment ça se fait qu'en France des cloches sonnent à chaque heure pour manifester la présence chrétienne ... et que les musulmans eux n'auraient pas

Michelle D. Weitzel

m.weitzel@unibas.ch

1 Department of Social Sciences, University of Basel, Spalenvorstadt 2, 4051 Basel, Switzerland 
le droit d'exprimer leur conviction religieuse. Alors soyons discrets jusqu'au bout et arrêtons toutes ces cloches."

How is it that in France the bells ring each hour to demonstrate a Christian presence, and yet Muslims don't have the right to express their religious conviction? So, let us be thoroughly discrete and stop all these bells.

Iman Abdelali Mamoun $^{1}$

Scholars of France often point to French politicians, media, and public intellectuals as the actors with the greatest ability to impact discursive framings and guide debate on hot-button issues of the day. These pillars of elite discourse, largely centralized in Paris and sharing common educational and class background, hold disproportionate sway, it is claimed, in shaping public attitudes and dictating the terms of public debate (Suleiman 1978; Bowen 2010: 3; Gumbel 2013). Their significant influence has been particularly noticeable in recent years on topics related to Islam in France, Muslim integration in French society, lä̈cité, the recurring headscarf affairs, and questions related to the substantive content of "Frenchness." Yet there is a fourth important actor, or "actant," engaged in these debates—one that operates across elite and plebeian niveaux but has largely escaped notice. ${ }^{2}$ This actant may be understood as common sense-with an analytical emphasis on the sensory connotations of the term. Common sense escapes notice both because it is empirically difficult to isolate and because it is so normalized as to be taken for granted.

Referring generically to reasonable judgement based on the straightforward perception of a situation, the presumed familiarity and imprecision of "common sense" marks it for easy dismissal as a topic of sustained scholarly inquiry, let alone as a key actant in politics. Yet other scholars, too, have pointed to the salience of common sense in shaping political outcomes. International relations theorist Ted Hopf, drawing on Antonio Gramsci's theory of hegemony, has argued that common sense should be seen as a structural variable that works its way through everyday practices of the masses - whether wielded consciously as a "weapon of the weak" (Scott 1985) or unconsciously through habitual conduct. Hopf writes, "a common sense that is at odds with an elite hegemonic ideology may impose political, that is selectoral or electoral, costs on an elite that ignores it. Failure to heed mass common sense may result in demonstrations against [...] policies, the emergence of alternative political parties and movements, and/or fractionation within the ruling party" (Hopf 2013, 323). Yet contra Hopf, whose theorization of common sense's hegemonic capacity derived from logocentric discourse analysis and the circulation

\footnotetext{
1 "L'imam Abdelali Mamoun Accuse les Cloches d'eglises de sonner," Les Observateurs, August 19, 2016. https://lesobservateurs.ch/2016/08/19/france-limam-abdelali-mamoun-accuse-cloches-eglises-desonner/.

2 "Actant" is a term coined by Bruno Latour to expand agentive capacity to include nonhuman forces. See Latour (2005).
} 
of ideas in social life, this article seeks to resuscitate nonverbal, intuitive, embodied experiences that feed into shared constructions of what constitutes reasonable judgement.

To this end, I invite readers to pause and reconsider the perceptive and interpretive acts embedded in the production of discursive knowledge, using contemporary France as a case study. Specifically, I want to focus on common sense in French politics by tracing individual and collective embodied knowledge generated by everyday ambient atmospheres, thereby drawing attention to the unconscious discernment involved in the process of the "simple" perception of situations and facts, as well as the relevance of this process for politics. In this reading, common sense, or collective sensing and knowing, is generated at the nexus of ambient sensory stimuli, human perception, and interpretation. Embodied knowledge on a range of civic topics may be derived from everyday experience in public space, yet the active role of this structuring force is often missed-not only in research on citizenship and religion but in political science literature more broadly.

This article offers an empirical, ethnographic investigation into one way common sense, in dialogue with constitutional and municipal law, manifests as a political actant that shapes practices of citizenship and participation in French public space. ${ }^{3}$ To empirically examine a phenomenon as diffuse as common sense and its relation to civic behaviors, I single out the sensory register of sound, tuning into prototypical public Christian and Islamic religious sounds, namely the ringing of church bells and the Muslim call to prayer, or adhan. ${ }^{4}$ It is generally the case that the adhan is not broadcast publicly from minarets in France. This is usually attributed to prevailing attitudes toward laïcité-a conclusion that has been stated with such certainty as to make further examination of the adhan in France seem unnecessary or even inflammatory. But this explanation does not provide an understanding of why the Muslim community of France-proportionately the largest in Europe-has not

\footnotetext{
3 This methodological choice may be seen as building on Hopf's call for further ethnographic research into common sense in politics. Hopf writes, "discourse analysis is only a second-best strategy for recovering common sense. An ethnographic recovery of the everyday in Russia and elsewhere should be preferred." (Hopf 2013): 350.

4 My focus on the sonic should not be heard as a privileging of one sensory register over another in terms of political import or relevance to public space. In recent debates on Muslim belonging and proper boundaries of "Frenchness," all the senses have been conscripted into political arguments. For example, it will come as no surprise, in particular to scholars of race, that a preponderance of voices doubting the ability of Muslims to perform as French citizens, or to "integrate," have centered their suspicions on physical, embodied practices. Social friction surrounding practices of halal eating, veiling and the headscarf debates, the burial of the dead, the appropriateness of female swim attire (from nudity to burkinis), sexual freedoms, and even the presence of physical bodies in the street (whether praying, loitering, or playing), converge on sensory expectations and ontologies. The senses are engaged synergistically in every interpretive encounter with civic space; singling out sound, and specifically religious sounds which are embedded in a variety of discursive and cultural frames, merely allows a more in-depth investigation into the process by which embodied knowledge interacts with, and influences, French politics of belonging. Focusing on visibility, Gerdien Jonker and Valérie Amiraux have recently posed a similar question, asking "What is the sanctioned space within which Muslims may act? How, in what specific areas, and with what intensity, are they allowed to act in terms of their own definitions in the European public sphere?" See Jonker and Amiraux (2006): 10.
} 
pressed this silencing as an issue of religious freedom as it has in England, the USA, Germany, and Sweden. What role does the adhan, and its public silence, play in French politics of belonging, and how, precisely, is the suppression of the adhan as a publicly aired religious sound reconciled with discursive normalization of ringing Christian church bells?

We have a limited understanding of how everyday sensory stimuli, in tandem with laws governing the use of public space and cultural expectations, generate hegemonic aesthetic norms that structure broad-ranging political attitudes in France. Thus, my empirical investigation into common sense politics is contextualized by contemporary debates on democracy and laïcité, and the supposed challenges the French Muslim community has faced in integrating into French society. A key takeaway is that common sense among non-Muslim French, deriving from perception and interpretation of public sound, represents a stubborn obstacle to the French Muslim exercise of full citizenship.

This research contributes to work that has highlighted the shortcomings of rights claims within Western democracies (Fredette 2014) and the racial and biological entanglements that plague taxonomic categories of race, religion, and culture in French discourse (Davidson 2012). It also offers further support for arguments that point to the ways in which concept of laïcité, despite its widespread usage, has been emptied of consensual substantive meaning and, in consequence, is commonly coopted for wildly different political ends. The hollowing of the concept of laïcité has been traced profitably through the lens of gender and racism (Fadil 2011; Fernando 2014; Selby 2012 and Scott 2007); through understandings of culture and identity (Barras 2013; Bowen 2010; Jouili 2019; Kastoryano and Escafré-Dublet 2016); and through public policy and debate (Ahearne 2014). This article complements this body of work by interrogating the entanglement of laïcité and the senses. In tuning into sonic forms of engagement, it takes literally Joan Scott's assertion that "creating a reality one wants requires ... the discrediting, if not silencing, of alternative points of view" (Scott 2007: 7 italics added). In so doing, it makes an empirical case for the political importance of embodied, sonic knowledge in shaping both discursive understandings of Muslim belonging in France and legal regimes that govern public space. It demonstrates how culturally entrained listening practices and habitual engagement with the sounded public environment structure rights to the city and the full exercise of citizenship, rendering embodied knowledge and common sense important actants in contemporary political debates.

Given its attention to religious sound in public space as a register by which to analyze French belonging, this article takes religiosity as a central premise. My interlocutors self-identified as Muslim, Catholic, or secular and were often engaged in debates on religion in public space by virtue of their official position or their physical proximity to churches or mosques. My depiction of religious practice, as well as my portrayal of the potential political impact of religious sound in public space, derives from conversations with subjects in the field, thus showcasing their diverse interpretations of appropriate religious practice. Fieldwork in support of this article took place between 2015 and 2018 and consisted of ethnographic research, interviews, and textual analysis of French national newspapers and constitutional and municipal law on the topic of religious sound. My ethnographic work involved eight 
discontinuous months of observation and listening in Paris, Marseille, and Le Puyen-Velay. In Paris, in June, July, and August of 2016, I rented a small apartment in the ethnically diverse Goutte d'Or neighborhood of the 18th arrondissement, close to l'Institute des Cultures d'Islam. I made contacts in the neighborhood through the institute and engaged in informal conversations and semi-formal interviews with Moroccan, West African, and Algerian residents and practitioners of Islam. In Marseille, in December and January 2016, I conducted walking ethnographies of the city's "basement mosques" to better understand the material, spatial, and ambient empirics of these sites of worship, using the "trouvetamosquee" website to identify mosque locations. In January and February of 2018, I lived with a family in Le Puyen-Velay, sharing their home adjacent to the Puy Cathedral where I heard the cathedral bell toll regularly. I participated in local events related to the Lycée St-Jacques de Compostelle where one of my hosts was employed, attended evening Arabic language classes at the Mosquée al Rahman, and engaged in informal conversations with diverse residents of the town. Over the course of my fieldwork, I conducted open-ended and relational interviews ${ }^{5}$ with municipal officers, historians, campanarians, Catholic priests and nuns, imams, experts at the Centre Information du Bruit, mosque and church officials, Muslim and Catholic residents in mixed neighborhoods, representatives of the "Vivre Ensemble" and "Association Lumière" cultural initiatives, officials at the Grand Mosquée de Paris and the al Ghazali Institute in Paris, public "experts" on Islam, and officers of Muslim Associations in Le Puyen-Velay and Saint-Étienne. Interlocutors were selected through direct contact and through snowball sampling. I also attended the March 2018 Rencontre Annuelle des Musulmans de France (RAMF) conference in Le Bourget, where I met and interviewed mosque officials from Strasbourg and a suburb north of Paris ${ }^{6}$ to broaden the scope of my data and understand how the findings I uncovered in Le Puy-en-Velay might relate to Muslim experiences in other French cities.

The claims I make cannot represent "French Muslims" uniformly, just as there is no single "French Muslim" community that speaks with a unified voice. ${ }^{7}$ My careful construction of the religious life worlds from which commonplace Catholic and Islamic practices emerge may nonetheless offer a valuable, and perhaps even broadly applicable, lesson on the active role of sensory perception in politics

\footnotetext{
5 "Relational interviewing" follows Lee Ann Fujii's call to conceptualize interviews as dialogue rather than one-way interrogation and foregrounds critical reflexivity and an interpretive approach to the interview "data" that derives from mutual sense-making occurring during the course of the conversation. See Fujii (2018).

6 A member of the Muslim Association of Anonymous City shared with me a politically sensitive story related to the mayor, iftar celebrations, and the call to prayer, but requested I not name his city in publication to protect from potential backlash.

7 Scholars have noted that Muslims in France consist of a heterogenous population including migrants from disparate origins and economic backgrounds, native-born converts, European and French citizens, foreigners, believers and nonbelievers, traditionalists, secularists, and radicals. French Muslims are male and female, span all ages and races, adhere to disparate sectarian norms, and enact their belief according to a variety of orthodox and unorthodox practices. With such diversity, scholars of French politics may expect a commensurate diversity in potential attitudes toward citizenship, civic duty, and belonging. For more on this topic, see Jonker and Amiraux (2006): 16.
} 
of belonging and debates on integration, and on the way that common sense may impact something as supposedly impartial and disembodied as law. It also represents a timely intervention into French debates on Muslim claims-making and their supposed "hypervisibility" in European public space.

In what follows, I begin with a brief overview of French law governing religious sound in public before turning to a case study examining the application of these laws at the municipal level in Le Puy-en-Velay, a town in central France with a prominent Catholic tradition and a French Muslim population of approximately 10 percent-a figure that aligns closely with national percentages which estimate total Muslim population in France to be at 8.8 percent (Hackett 2017). I discuss interpretations of these sounds by local residents who experience them and make sense of them as everyday components of their civic soundscape. Approaching common sense through thick description in a single sensory register makes it possible to render transparent residents' reasoning rather than imputing explanations from an external vantage point. Finally, I analyze the political impact of sound-based forms of common sense in structuring rights claims in urban space, läicité, and national belonging.

\section{Regulating religious sound: the 1905 law}

The French state's approach to religion since the French Revolution has been one of non-interference, often summed up in the concept of laïcité, wherein the State protects "free thought" from religious influence, maintaining particular vigilance over public space and schools. Article 1 of the French Constitution of 1958 states, "France guarantees equality before the law for all of her citizens, without reference to origin, race, or religion. France respects all beliefs." Similarly, the first article of the 1905 loi de separation des Églises et de l'État, commonly cited in debates on laïcité, states that the Republic "guarantees freedom of conscience and the free exercise of religion, so long as the worship does not disturb public order." ${ }^{\text {" At the high- }}$ est levels, then, laws governing religion in public space treat recognized religions equally. ${ }^{9}$ Put differently, French citizens have equal rights under law to practice their religion and express their religious convictions, or lack thereof, in accordance with their beliefs. Encompassed in the freedom to manifest convictions, Article 27 of the law specifically protects religious sound:

Ceremonies, processions and other external manifestations of a religion are regulated in accordance with article L2212-2 of the general code of local

\footnotetext{
8 The original text of Article 1, Loi du 9 décembre 1905, regarding the separation of church and state reads: "La République assure la liberté de conscience. Elle garantit le libre exercice des cultes sous les seules restrictions édictées ci-après dans l'intérêt de l'ordre public. Legifrance.fr https://www.legifrance .gouv.fr/affichTexte.do?cidTexte=JORFTEXT000000508749.

9 To be more precise, the law does not officially treat Muslims differently from other French citizens (although some have protested that the ban on the wearing of "ostentatious" religious signs in public space singles out Muslims unfairly).
} 
authorities. [N.b. Article L2212-2 concerns itself with the maintenance of public order, safety, security, and health.] Bell ringing will be regulated by municipal decree, and, in case of disagreement between the mayor and the president or director of the religious association, by prefectural decree. The Conseil d'États determines the cases in which civil ringing may occur. ${ }^{10}$

Although applied to all recognized religions, the text of the law refers explicitly and exclusively to bells as the singular conveyors of religious sound, in line with norms stemming from France's Christian heritage. ${ }^{11}$ The law inscribes the secular State's final authority over when and how often church bells may sound; city mayors, not church officials, are granted jurisdiction over the ringing of church bells, with regional prefects serving as higher powers in the event that a dispute cannot be solved at the municipal level. ${ }^{12}$

In keeping with the premise of protecting religious freedoms, Article 27 authorizes the mayor to regulate bell ringing; however, she may not prohibit sound "such that the practice of worship is hindered" as determined by an administrative judge. ${ }^{13}$ For example, in a 1994 court case the French Conseil d'État ${ }^{14}$ ruled that the ringing of the Angelus bell prior to 7 a.m. could not be prohibited because of the religious nature of the sound, which did not, it was judged in this case, disrupt public

\footnotetext{
10 The original text of Article 27 of the 9 December 1905 law reads: "Les cérémonies, processions et autres manifestations extérieures d'un culte, sont réglées en conformité de l'article L2212-2 du code général des collectivités territoriales. Les sonneries des cloches seront réglées par arrêté municipal, et, en cas de désaccord entre le maire et le président ou directeur de l'association cultuelle, par arrêté préfectoral. Le décret en Conseil d'Etat prévu par l'article 43 de la présente loi déterminera les conditions et les cas dans lesquels les sonneries civiles pourront avoir lieu." Legifrance.fr. https://www.legifrance.gouv.fr/ affichTexte.do?cidTexte $=$ JORFTEXT000000508749\#LEGIARTI000027973675.

11 This is unsurprising given the date the law was adopted. Despite long-standing colonial relations, Muslims did not begin arriving in continental France in significant numbers until the 1950s and 1960s, well after the 1905 law was drafted and put into effect. The period from 1848 to 1962 when colonial Algeria was fully incorporated into France as an administrative Department, represents an interesting anomaly - the Muslim call to prayer was permitted, but the physical separation of communities, and the ghettoization of Muslims, meant that Islamic religious sounds were less prominent in place like Algiers and Oran.

12 In 1906, following the passage of the 1905 law, mayors across France issued decrees regulating religious sound. These were sent to the local church officials, who had 15 days to submit written complaints of oppression to the town hall, after which the mayoral decree became law. The decree stipulated, in part, that religious bells may be requisitioned by the state for use in the event of a common danger. See Corbin (1998). It also specified that the mayor must be given a key to the bell tower, but that he may only ring the bells in cases of civic emergency or the maintenance of the public clock. 16 mars, 1906 decree, Article 50 (consolidated version, updated April 7, 2018).http://www.legifrance.fr.

13 Christophe Sanson, a French lawyer specializing in sound in public space, notes: "si l'article 27 de la loi sur les cultes de 1905 autorise le maire à les réglementer, il ne peut le faire "dans des conditions telles que la pratique du culte s'en trouve entravée' selon le juge administratif." Personal correspondence with Sanson. This phrasing is presumably particularly problematic for the adhan, since judgement of whether or not its prevention hinders the practice of worship would likely fall to a jurist untrained in Islamic theology and who may have little knowledge of the religion.

14 The Conseil d'État is a body of the French national government that acts as both legal advisor to the executive branch and as the supreme court of appeal for administrative law courts.
} 
tranquility. ${ }^{15}$ In another case, it was decided that mayors may not arbitrarily prohibit church bells rung for approved civil purposes without reference to local custom. ${ }^{16}$

Constitutional law protects Christian bell ringing in line with the normative protection of the freedom to manifest religious belief, but it delegates the authority to regulate this sound to municipalities, thereby deferring to local custom and granting power over the sensory environment to the office of the mayor. Thus, municipal public space becomes a laboratory for examining the interaction between local forms of knowledge and meaning, on the one hand, and national principles, on the other. In practice, bell ringing varies greatly from one church to another, as well as across cities and regions of France. Similarly, despite a prominent Muslim presence in many municipalities, French Muslims, generally do not attempt a public broadcast of their call to prayer. Thus, in spite of this formal legal equality, an attention to the sonic register reveals that when constitutional principles are applied in municipal politics at the level of the street, we may observe that the interpretation of formal law relies on embodied forms of knowledge and culturally constructed sensory regimes. In France, particular aural knowledges and norms dictate acceptability of religious sound in public, and even dictate what counts as "evidence," or perceptible criteria, upon which the law may be applied. Understanding common sense, embodied interpretations of the law reveals that the ideal republican "difference blind" model is not, in fact, "difference deaf" in practice-nor indeed indifferent to any form of sensory alterity. As Nilüfer Göle and others have noted, Islam in France is rarely controversial in terms of institutional or textualized forms of subjectivity; rather, social dispute is visceral and "carried by corporeal performances and self-presentations" (Göle 2002, 183). Put otherwise, difference is easier to ignore, and thus tolerate, when it is abstract.

In order to understand how this plays out, and to discuss with specificity the regulation and broadcast of religious sounds in one setting, the following section presents a case study from the town of Le Puy-en-Velay in the Haute-Loire. The town is renowned for its Catholic character, but Puy, as it is commonly called, also has a small Muslim population with historic ties to Morocco. In 2011, Puy's primary mosque became the target of attention in right-wing media in which it was accused of broadcasting the adhan. The possibility of a pluralist religious soundscape made this town of $18,909^{17}$ a fruitful field site for questions related to mediating cultural and religious diversity in public space.

\footnotetext{
15 Personal correspondence with Sanson. Case: CE, 11 mai 1994, no 137612, Larcena. JURIBRUIT, Lutte contre les bruits de voisinage (édition 2015) Série A.

16 Personal correspondence with Sanson, Case: Tribunal Administrative, Lille, Jan. 15, 2004, no. 03-2844, Duavrant et al. This reference to "local custom" again puts the adhan at a disadvantage because a judge may presumably rule that this sound is excluded from local custom.

17 “La population a gagné 3.028 habitants," l'Éveil de la Haute Loire, January 2, 2018. https://www.levei 1.fr/puy-en-velay/economie/haute-loire/2018???/01/02/la-population-a-gagne-3-028-habitants_12687147. html.
} 


\section{Le Puy-en-Velay: religious sounds and the right to the city}

Located along the famed pilgrimage route to Santiago de Compostela, Le Puy-enVelay has a long and rich association with the Catholic Church. In the Middle Ages, it was the seat of a major bishopric, and its cathedral, the Cathédral Notre Dame du Puy, has been an essential destination for pilgrims since the time of Charlemagne. Within an area of 6.48 square miles, Le Puy-en-Velay boasts 19 churches and one Islamic prayer room, as well as one freestanding mosque on the edge of town.

In February 2018, a month not marked for religious occasions, the three christened bells of the Puy cathedral rang in a "civic" capacity every hour between 7 a.m. and 10 p.m., as well as ringing one chime to mark every quarter hour. In an explicitly religious capacity, the bells also rang twice each day for Mass, ${ }^{18}$ which included a fifteen-minute forewarning chime as well as the actual Mass bells; they rang for special Catholic occasions on February 2, 4, 6, 8, 11, 14, 22, and 27. On four of these days, the cathedral bells were rung using a "festive" technique, which involves multiple bells and a prolonged ringing engagement, two or three times throughout each day. ${ }^{19}$ With this irregular ringing, the bells continue the custom of marking life events such as births, baptisms, weddings, and deaths, vociferously ringing in life cycles and marking time according to a biological clock. The other 18 churches in Puy ring as well, with the result that bell chimes may be heard frequently each day and throughout the day, for irregular lengths, with varying significations, and emanating from varying geographic points within the city.

Emanuel Rolhion, a civil servant in charge of municipal relations at the mayor's office, said that to his knowledge, there were no legal restraints on religious sounds in Puy. ${ }^{20}$ "If there is a complaint," he explained, "then the mayor's office has to intervene more fully. We will launch an investigation and eventually issue an arrêté municipal detailing precisely what steps need to be taken to restore public order." He confirmed that Monseigneur Crespi, the current Bishop, was free to ring the Cathedral's bells all day, if he deemed it appropriate, but pointed out that the Church was bound by its own laws and that bells were rung in accordance with a precise Catholic schedule. ${ }^{21}$ "The mayor only intervenes in religious sound if there

\footnotetext{
18 Mass times vary with the seasons and the weekdays. Over winter from November 1 through March 31, during which time I did fieldwork, Mass was offered in the Cathedral at 7:30 a.m. from Monday to Friday, and at 10:30 a.m. Monday through Saturday in the Chapel of Relics as well as on Sundays in the Cathedral. In spring and fall, (April, May, June, September, and October) the morning Mass bell rings at 7:00 a.m. In July and August, during the height of the pilgrimage, Mass is performed every day at 7 a.m. in the Cathedral, at 10:30 on Fridays, Saturdays, and Sundays, at 17:00 Monday through Thursday in the Chapel of the Relics, and at 17:00 on Fridays in the Chapel of the Penitents. For updated schedules, see le Cathédral du Puy, https://www.cathedraledupuy.org/vie-de-la-cathedrale/horaires-messes-et-offices/ horaire-des-messes.

19 On February 8, the Marie-Joseph rang off schedule on my behalf when Père Bernard Planchetitle, "rector of the Cathedral," demonstrated the controls, now mechanized and operated from a small office next to the Cathedral sacristy, which set the bells into motion.

${ }^{20}$ Interview with the author. February 6, 2018.

21 Planche confirmed this, noting "the Church takes it upon itself to decide which rings are 'necessary' and which are not. Interview with the author, February 8, 2018.
} 
is a complaint or a problem, so, when necessary. But otherwise there is nothing civil that governs the ringing of bells," Rolhion said. Rolhion was not alone in this opinion. Jean Jacques Liotard, the premier adjoint to the Mayor of Puy, said "there are no laws governing church bells, or, if there are, they were written very long ago and have since been forgotten. Today the church does more or less what it likes, and as long as there are no complaints about tranquilité, the mayor stays out of it." 22

The same is not true for Islamic religious sounds. In contrast, Le Puy-en-Velay's mosques, the Mosquée de la Bienveillant in the center of town, and the larger Mosquée al Rahman, would be required to file for a permit with the city in order to amplify their call to prayer because, as Rolhion explained, "establishments are not allowed to use loudspeakers to transmit sounds" according to municipal noise control laws. ${ }^{23}$ The mayor may authorize the adhan by granting an exemption against the injunction of the use of loudspeakers in public space, but Rolhion said that, to his knowledge, the mosque had never petitioned the city to broadcast the call. He added that if the sound were to spark public controversy and come under legal scrutiny, a judge's decision would be based on decibel levels but would also take into account the nature of the sound, the nature of the complaints, and the overall norms and expectations of the city's residents. "At the end of the day," Rolhion said, "it's a bit subjective." 24

\section{Common sense as the arbiter of exclusion}

Despite the frequency of bell sound, many people in Puy, when asked, claimed not to hear bell chimes in their town. ${ }^{25}$ The question was fielded with some surprise, which often led to musing and then statements such as "well, yes, I suppose the Cathedral does ring the hours...." A few residents went so far as to vehemently deny the presence of any religious ringing - citing personal knowledge and embodied experience ("I have never heard it") as evidence for their stance. While there was a general awareness of the bells, non-Muslim Ponots I spoke with were unable to tell me of their individual signification when asked. This excludes Father Bernard Planche, in charge of ringing at the cathedral. Planche suggested that while most residents of Puy (or Ponots) today were unlikely to know precisely what each ring tone signified, they might plausibly figure it out from context. As Planche noted with some regret, “there are no special ways of training citizens' ears anymore-it's simply a matter of accustomization." In his opinion, contextualizing the bells was made easier by the

\footnotetext{
22 Interview with the author, February 7, 2018.

23 Interview with the author. February 1, 2018.

24 Interview with the author, February 1, 2018.

25 This claim is based on informal conversations with townspeople of Le Puy-en-Velay. I resided in the medieval "Haute Ville" neighborhood, on a street immediately below the cathedral grounds where, appropriately tuned in, I heard the bells regularly. Among my immediate neighbors, people either claimed they rarely heard the bells, or made mention of their civic capacity to ring the hours. Outside of this neighborhood, people occasionally mentioned the Cathedral's ringing on holidays, but the overwhelming attitude was that bells rarely rang anymore.
} 
fact that the tempo of the ringing often correlated with its subject-weddings were celebrated in a joyous, upbeat style that set the bells swinging; funerals, in contrast, were rung with single, echoing, taps. ${ }^{26}$

The Ponots' deafness to church bells may be understood as a double silence: first, bells are audible but unheard because of a subjective and culturally conditioned capacity to tune out some types of sound; and second, the ability to distinguish among bell chimes, or to understand the denotative content of the sound, has been lost, silencing its signification. In everyday experience, then, bell ringing is "dissolved" into background noise that forms the neutral baseline from which residents pay heed to their ambient surround, leading to an expansive conception of "silence" and tranquilité that enfolds, among other things, bell sounds. Church bells that resound across public space without the benefit of inherited or normed meanings speak to a tangible, empirical transformation of culture-representing an affective echo of earlier practices that lacks precise societal mooring in the contemporary era. As such, common sense represents a mechanism by which church bells come to be constructed as cultural rather than exclusively religious in legal contexts, even as analysis of the sensory perceptions underlying mainstream notions of common sense reveals the blurring of religious and cultural categories in society more broadly. ${ }^{27}$

In support of the notion that bells are either not perceived or ignored as "normal" ambiance, lawsuits challenging bell ringing are infrequent in France. A March 2018 search on www.bruit.fr, a French organization dedicated to tracking noise complaints and the regulation of environmental noise, revealed six court cases that dealt with church bell ringing, spanning the period from 1974 to $2005 .^{28}$ When lawsuits do occur, courts fall back on broader noise regulation laws to adjudicate disagreement, but often rule in the Church's favor nevertheless. In the northern French city of Douai for example, a city celebrated for its 80-meter Gothic belfry dating to 1380 , and its 62-bell carillon that spans five octaves, residents living near the cathedral

\footnotetext{
26 Interview with the author. February 6, 2018.

27 Lori Beaman explores these questions further in her recent book Beaman (2020), in which she argues that culture and religion are increasingly conflated in law and public discourse. Examining court cases in France, Canada, and the USA, Beaman shows how religion is transformed into culture by courts in order to uphold democratic principles separating Church and State while at the same time accommodating, or making room for, the affective preferences and expectations of the majority. Other recent and prominent court cases where these issues have come to the fore include Lautsi v. Italy, where a court ruled that a crucifix in the classroom represented Italian civilizational values and did not have religious connotations; and Sedlock v. Baird, where a court ruled that Ashtanga yoga in schools constituted a secular activity and as such did not violate students' religious freedoms or state constitutions. In contrast, in a court case where the symbol in question was framed as explicitly religious (in this case, a hijab worn by a teacher), a Swiss court ruled that the school district's demand that the teacher remove her hijab was "necessary in a democratic society." See the European Court of Human Rights, Case of Lautsi and Others v. Italy, Judgment, Strasbourg, March 18, 2011; Court of Appeal, Fourth Appellate District Division One, State of California, Stephen Sedlock et al v. Timothy Baird et al. Super. Ct. No. 37-2013-00035910-CU-MCCTL; and European Court of Human Rights, Case of Dahlab v. Switzerland, Judgment, February 15, 2001. Online: https://www.servat.unibe.ch/dfr/em423939.html. I am grateful to an anonymous reviewer for drawing my attention to these cases.

28 This cannot be considered exhaustive because the organization self-selects which cases to report. However, Sanson reported in personal correspondence that lawsuits against religious sound are rare.
} 
filed a noise complaint, claiming the bells were disruptive. The court authorized sound specialists to take noise measurements at the plaintiffs' property and found that the bell clangor at the location of the complaint registered under the city's decibel limit for disruptive noise. ${ }^{29}$ Thus, the administrative court ruled in favor of the mayor (who in this case had sided with the Church and refused to moderate the bell ringing). If the bell sound had exceeded the city's guidelines for noise, the judge could have asked the church to attenuate the ringing, but he would not have the authority to eliminate it entirely.

The primary mosque of Le Puy-en-Velay tried for a brief period to broadcast the adhan beyond its walls. The Muslim Association of Puy never asked the city for official permission to broadcast the adhan, but they did mount a small loudspeaker on the chimney of the old farmhouse, now refashioned as a discrete minaret and topped with an unobtrusive crescent moon. President Mohamed Boussikli said the mosque broadcast the adhan from the loudspeaker, particularly around Muslim holidays, but never received complaints from neighbors. At approximately 10 percent of the population of Puy, Muslims are a minority, but in terms of the spatial distribution of domiciles, there are "clusters" where Muslims constitute a majority of inhabitants. ${ }^{30}$ The loudspeaker is mounted on the side of the building facing the parking lot, and Boussikli indicated that mosque-goers found it useful, particularly as they were approaching, because it gave them a sense of how much time they had before the prayer began. He added that hearing it gave the congregation a sense of joy and pride during the holidays. ${ }^{31}$

Located to the southeast on a ridge that encircles the town basin, ${ }^{32}$ the Mosquée al Rahman was built on farmland in 1990. It is separated from central Puy by train tracks, but there is a small, mixed, lower-income residential community, officially designated a zone urbain sensible, of ZUS, along the flank of the ridge leading up to the mosque. The mosque abuts a commodious parking lot which stands empty most of the time, but fills up on annual celebrations such as Eid al Kebir, when attendance swells to between 400-700 people. On a typical day, between 10 and 20 Muslims come to pray. ${ }^{33}$ The mosque's closest neighbor is a large, covered sports facility with

\footnotetext{
${ }^{29}$ Noise regulation classified under environmental concerns, or nuisances sonores, is similarly regulated by city-by-city, although nationwide guidelines exist in accordance with the European Commission's Environmental Noise Directive. Directive 2002/49/EC may be found online: https://ec.europa.eu/envir onment/noise/directive_en.html.

${ }^{30}$ The French state does not include religious information in its census questionnaire, making official figures on religious subsets difficult to obtain.

31 Interview with the author. January 28, 2018. It should be noted that none of the non-Muslim French I spoke with had heard the adhan in Puy. The mosque is sufficiently at a remove, and the loudspeaker setting sufficiently low, that most respondents claimed my questioning was the first time they had thought of it.

32 Puy also has a small Islamic prayer hall in the town center, called Mosquée de la Bienveillante on Rue Général Lafayette. This mosque appeared to be inactive during my fieldwork time in Puy; officials did not return phone calls and the entrance remained locked and unattended.

33 In February 2018, the Mosquée al Rahman had 184 "official" members, that is, adherents who make monthly donations to the upkeep and running of the mosque (averaging approximately 10 Euros per person). In a nod to transparency, the members' names are listed on a bulletin board in the entrance hall, with their respective donations noted next to their names.
} 
community basketball courts and a swimming pool; a little further down the road, an equestrian center is surrounded by pastureland. The mosque is open to all, but it was founded and continues to be run by Muslims of Moroccan ancestry with ties to the city of Meknes. The congregation follows the Maliki school of Islamic law.

The broadcast of the adhan may not have upset any neighbors willing to engage mosque officials directly, but it came to the attention of a number of French bloggers and right-wing media outlets who sent a representative to interview Boussikli and then, in rhetorical outrage over the presence of an adhan in French territory, reblogged video footage of his "admission" widely. The interview shows Boussikli in the front of the mosque, with the loudspeaker visible in the background. He is filmed saying the mosque never had any complaints about the sound. The following excerpt by Catherine Segurane, writing for AgoraVox, Le Media Citoyen, is representative of the reporting that followed. ${ }^{34}$ Segurane writes:

In theory, the minarets built in France are not intended for the call to prayer. In practice, several examples have been discovered. They were clandestine at first, but they have even dropped this pretense. [...] What did we hear when we dared [suggest that minarets would lead to prayer calls?] "No, no, no, never would a Muslim think of performing the adhan in Europe. To suspect them was pure Islamophobia. The minaret was a simple architectural element. Promised, sworn, sealed. In reality, promises are only binding on those who believe in them, and examples of the call to prayer, either already being performed, or soon to follow, are multiplying. ${ }^{35}$

Segurane charges mosques in Nanterre and Montluçon likewise of sounding the adhan. Other bloggers piled on, accusing mosques in Meaux, Bethoncourt, and Marseille of the same offense. ${ }^{36}$ The anti-Islamic and xenophobic Riposte Laïque and l'Observatoire de l'Islamization posted what appeared to be a video of Laurent Wauquiez, at the time the mayor of Le Puy-en-Velay, speaking in favor of the mosques' call to prayer. ${ }^{37}$ The video, which contains awkward cuts that suggest amateur editing, was likely cobbled together to suit a political end. Liotard denied the report that Wauquiez, his former boss, would have authorized the Mosque to call the adhan, saying flatly that it did not happen. A life-long resident, Liotard had never heard the adhan in Puy, but added that the mosque was sufficiently far away that a prayer call was unlikely to be audible. Liotard suggested that the Riposte Laïque

\footnotetext{
34 See Nilsson (2019) for a discussion of how radical-nationalist sentiment and anti-Muslim sentiment has played out in popular media. Specifically, Nilsson presents a case study of Riposte Lä̈que to showcase how this populist media outlet has impacted debates on laïcité. See also Stockemer (2014): 36-58, for background on the political values and personal beliefs that unify members of the Front National.

35 Catherine Segurane, "France: du Minaret à l'appel à la prière," AgoraVox: Le Média Citoyen, August 16, 2011. https://www.agoravox.fr/actualites/religions/article/france-du-minaret-a-1-appel-a-la-99011.

${ }^{36}$ In addition to Agora Vox, Right-wing blogs that either reposted the original article or wrote versions of their own include Enquetes et Debats, Observatoire de l'Islamization, FrançaisdeFrance Blog, Chretiens Libres Blog, Islamization.fr, Les4Verités Blog, Des Domes et des Minarets.

37 Leonidas, "L'appel à la prière retentit au Puy-en-Velay, avec la benediction de Laurent Wauquiez," Riposte Lä̈que, June 3, 2011. https://ripostelaique.com/lappel-a-la-priere-retentit-au-puy-en-velay-avecla-benediction-de-laurent-wauquiez.html.
} 
article was best understood as a political attack against Wauquiez, capitalizing on the "lightening rod" reaction the adhan issue was certain to evoke among its readers. The statement highlights the political salience that such seemingly small-scale, visceral civic encounters wield: journalists and politicians alike seize upon embodied markers of difference because they trigger powerful reactions-reactions that often span the Left-Right divide as they do not demand intellectual engagement or deliberation, but rather rely on common, presumedly pre-cognitive gut-feelings. ${ }^{38}$

In 2013, the Puy mosque was the target of two hate crimes. In one incident, mosque-goers found a garbage bag containing a severed pig's head wrapped in a French flag on mosque property. The mosque's CCTV surveillance footage revealed that it had been deposited in a drive-by; the sedan was not local but had a license plate from nearby Lyon. In the wake of the act, mosque officials retrenched. They left the loudspeaker installed but used it only on religious holidays and at a very low volume, generally reverting to calling the adhan inside mosque walls and leaving its public broadcast aside.

Although the political right has been the most outspoken against the sound, the adhan has long met with widespread disapproval in the French public: a 1989 IFOP survey of French opinion found that more than one-third of French people are opposed to the construction of mosques because of their prominent visibility (the height of the minaret) and the supposed noise disturbance of the call to prayer. ${ }^{39} \mathrm{~A}$ follow-up survey five years later found that, while negative attitudes toward minaret heights had fallen in favor of people who characterized themselves as "indifferent," opposition to the prayer call remained as solid as before. ${ }^{40}$ Former President Nicolas Sarkozy, capitalizing on this sentiment in 2010, and speaking on the topic of immigration, said "that there should be places of worship for Muslims is quite normal, there are more than 2000. But in France, there is no minaret, there is no muezzin that makes the call to prayer," adding that he hears his compatriots when they say, "we want to stay in France, the France that we love."41

The reasons behind the disapproval are complex, but one element that contributes to its negative reception is the way in which the sound, and particularly the takbir, or the

\footnotetext{
38 This contributes important empirical evidence for arguments on the role of empathy in polarization. Studies have pointed to empathy as a key mechanism in intergroup conflict, with a lack of empathy contributing to partisan polarization. I suggest that embodied knowledge and common sense may be salient in generating the affective positionality embedded in empathetic understandings. For more in this vein in the context of American partisan identities and polarization, see Simas et al. (2020): 258-269.

39 Robert Sole and Henri Tincq, "Le rejet de l'Islam et l'attrait de la France Selon un sondage IFOP, plus de deux Francais sur trois ont une image très negative de l'Islam et neuf musulmans sur dix jugent leur religion compatible avec l'integration," Le Monde, November 30, 1989.

40 "La France et l'Islam: Les resultats du sondage de l'IFOP la Religion et la Loi," Le Monde, October 13, 1994.

${ }^{41}$ In the original text: "Qu'il y ait des lieux de culte pour les musulmans, c'est tout à fait naturel, il y en a plus de 2000. Mais en France, il n'y a pas de minaret, il n'y a pas de muezzin que fait l'appel à la prière," a-t-il dit, expliquant "entendre ses compatriotes que me dissent "on veut rester en France, la France que l'on aime." Quoted in Nicolas Gaudichet, "Immigration: Sarkozy inflexible sur le fond," Agence France Presse, 17 November 2010. Archived at http://www.icare.to/news.php?fr/201011\#IMMIGRATION:\%20SAR KOZY\%20INFLEXIB LE\%20SUR\%20LE\%20FOND\%20(Franc e)(France).
} 
first line of the call to prayer, has been associated discursively with terrorism in popular media. ${ }^{42}$ Instances of such reporting range from news reports of the Charlie Hebdo shooters' shouting “Allahu Akbar" as they entered the building, to Muslim protesters chanting in streets, ${ }^{43}$ and to the cooptation of the takbir by three non-Muslim French minors in Bezier who prank-called "Allahu Akbar" over the public announcement system on a train in southeastern France before threatening to kill the train's occupants in a fake terrorist attack. ${ }^{44}$ French media treatment of the adhan largely falls into two categories - either it is referenced in a descriptive sense, often in the context of evoking "exotic" Oriental alterity, or it is cited in association with terror attacks and violence. ${ }^{45}$

Although public opinion and intimidation have played a role in silencing the adhan, there are without doubt more prosaic explanations for the absence of the Muslim prayer call in France as well. As voluntary associations, many mosques struggle financially, drawing most of their operating budget from the donations of their members. ${ }^{46}$ As such, they have limited funds for full-time employees; a dedicated muezzin is often not a financial possibility. Often the imam doubles as the muezzin and calls the adhan, or, as in the case of the Mosquée al Rahman in Puy with its small daily congregation, any male member of the jammah may perform the duty. The mosque's constituents rotate informally so that no one person is permanently responsible. In a context where communities have faced long uphill battles to find physical space for worship, the question of the adhan has often simply had to wait.

\section{Silence as a political strategy}

Although the Mosquée al Rahman did not field complaints from their immediate neighborhood in the wake of the broadcast, the Muslim Association of Puy has proceeded cautiously with regard to their loudspeaker since 2011. Abdel El Hamri, the association's long-time treasurer, said that the threat resonates among the general population because most people are aware of the dawn prayer and, regardless of their political leanings, do not want to be roused from sleep unnecessarily. El Hamri

\footnotetext{
42 Shenila Khoja-Moolji writes "The sounds of 'Allahu Akbar' ...often feature as cinematic strategies, preceding — or in the background of - acts of spectacular violence. ... 'Allahu Akbar' is part of an acoustic ecology that includes the Muslim call to prayers as well as the music from the Middle East often deployed in mediatized forms to signal a shift in time-space; a tentative entrance into the geographies, cultures, and times of an imagined "other." See Khoja-Moolji (2016): 1111.

43 Boris Thiolay, "Un imam trop républicain?" L'Express, no. 3063, March 18, 2010.

44 "France jusqu'a 30 mois de prison pour des jeunes ayant fait croire a un attentat dans un train," Agence France Presse Infos Mondiales, 9 December, 2015.

45 This representation is not specific to France. A Magistrate Court in Jerusalem announced in 2016 that the words "Allahu Akbar" may constitute a breach of peace and be the basis for a conviction for disturbing the peace. See Friedman (2016).

46 On the financial precarity of mosques, see for example: Yann Thompson, "Islam: comment peut-on financer les mosques de France?" franceinfo, August 3, 2016.
} 
explained, however, that the population had nothing to worry about because mosque officials took it upon themselves to limit the adhan. ${ }^{47}$ As El Hamri put it:

no one wants to heap problems upon problems-Muslims in France have enough problems as it is. Islam is new for French, Christians, and Catholics. It will really bother people if we start calling the adhan and it might turn the people of Puy against us. The people of France simply won't accept an adhan. Consider that there are more than 20,000 inhabitants in Puy, and of those, only about 2000 Muslims. We can't impose our will. ${ }^{48}$

Muslims of Puy have chosen public silence as a means of warding off debate and controversy, much like French Jews before them who had good reason not to draw audible attention to themselves. ${ }^{49}$ At its most basic, silence represents a course of action by which to protect their interests; a political decision to "hunker down" in an uncertain environment. ${ }^{50}$ In understanding this decision, it becomes clear that French law does not afford the same protection to French Muslims as it does to French Christians in terms of access to the city and rights to claim public sound waves for religious worship. Common sense conceptions of the proper aesthetics of public space help this inequality to fly under the radar. In Caitlin Killian's words, "although all religion in France is supposed to be private, the cultural climate and calendar are conducive to practicing Catholicism, while we have seen, they are not conducive to practicing Islam. The requirement that people bear no distinctive signs of religious belonging and yet they inhabit everyday life that is rhythmed by the Christian calendar forces observant Muslims and Jews to make a choice. They can be either good French citizens and bad Muslims or bad Jews, or vice versa" (Killian $2007,314)$. The mechanisms at work in the imposition of aesthetic standards on public sound echo Michel Foucault's description of how governmentalized expressions of shared value are enforced (Foucault 1980, 55), and point to how Christian hegemonic norms permeate everyday experience in France in ways that are in tension with universal, secular, liberal state claims. Specifically, the strategy of maintaining public silence highlights the inability of French Muslim citizens to claim the same rights to the free practice and expression of religious conscience as French Christians.

With a few aberrations that have not made national news, the choice to silence the adhan - to self-censor this call in a public context-is one that has been made by almost all mosques across France. Mohammed Moussaoui, the former president of the Conseil du Culte Musulman de France, affirmed in 2009, "the song of

\footnotetext{
47 Interview with the author. February 3, 2018.

48 Interview with the author. February 7, 2018.

49 On Jewish circumspection in France, see Kaplan (2011).

50 The idea that the French Muslim community censors itself is not new; see Kepel (1991): 283. Selfcensorship in this context may also be read simply as internalized agreement with notions that religion belongs in the private sphere. Jonker and Amiraux have suggested that the fact that most French Muslims do not wish to highlight their religious identity in public is at odds with public discourse that overemphasizes religion in explaining the actions of "Muslim populations." See Jonker and Amiraux (2006): 37.
} 
the muezzin to call the prayer has never been demanded by French Muslims. The minaret allows for the identification of [the building as a] place of worship, just as the bell tower does in a church." ${ }^{51}$ He repeated this claim in 2011, saying, "minarets have never been used to call the adhan, and the Muslims of France have never requested to call the adhan, as certain people pretend." 52 Djelloul Seddiki, Director of the al Ghazali Center at the Grand Mosquée de Paris, sees this as a wise practice. He counsels patience and advises taking things slowly as minorities in a Christian country, saying, "maybe in 100 years we can call the adhan here.",53

Maintaining silence has effects beyond straightforward defense, however, and can range into the realm of agency or even constitute a modality of resistance. ${ }^{54}$ Not broadcasting the adhan, for example, may act as a signaling device within the Muslim community, indicating that a given mosque is apolitical and that it seeks to practice Islam outside of the limelight and in line with Republican values. In this manner, public silence shapes political positionality actively and is not merely an impotent response to external forces. It likewise represents a withdrawal from full participation in what is perceived as a political process characterized by asymmetrical and disadvantageous power relations. ${ }^{55}$ While the salience of silence as a signaling mechanism is difficult to assess scientifically in France, given the limited number of mosques that have attempted to broadcast the prayer call, Bernard Godard, Islam specialist and retired officer of the French Renseignements Généraux, ${ }^{56}$ gives an illuminating counterexample. Godard explained that some mosques and prayer halls in suburban, Muslim-majority neighborhoods of Marseille call the adhan with

\footnotetext{
51 Ségolène Gros de Larquier, "Les minarets en France, des tours rares et silencieuses," Le Point, November 30, 2009, modified le 1 December 2009.

http://www.lepoint.fr/actualites-societe/2009-11-30/analyse-les-minarets-en-france-des-tours-rares-etsilencieuses/920/0/400007.

52 In the original text: "ces minarets n'ont jamais servi pour l'appel a la priere et le musulmans de France n'ont jamais fait la demand d'appel a la priere, comme le prétendent certains." Bertrand Langlois, "Debat sur la laicite: les musulmans en ont marre d'etre les bouc emissaires," Agence France Press, March 20, 2011.

53 Interview with the author. March 3, 2018. Seddikki's attitude may reflect the Mosquée de Paris and the Conseil Français du Culte Musulman's position as the French State's chosen interlocutor on Muslim affairs but it should not necessarily be understood as unerringly representative of French Muslim attitudes more broadly. Beyond the institutional affiliation, there may be generational factors at play in Seddikki's position as well. For example, conversations with Muslim university students in Lyon revealed starkly different attitudes. These students felt that the absence of a publicly aired adhan was yet another example of the unequal treatment that Muslims experience in France, and one that required active and immediate redress at a political level through activism and education. Groups conversation with the author. February 13, 2018.

54 There is a burgeoning literature theorizing silence in international relations, critical theory, and sound studies. While a full treatment of this literature falls outside the scope of this paper, readers seeking an overview might consult Sophia Dingli and Thomas Cooke's edited volume (2018), as a starting point. Xavier Guillaume and Elisabeth Schweiger's chapter, "Silence as Doing," highlights the ambiguities inherent in silence, which by its nature conceals its meaning and whether it intends a meaning at all.

55 For further discussion on how silence may serve as a strategy to undermine or resist asymmetrical power, see Ferguson (2003): 54-58.

56 The Renseignements Généraux is the intelligence branch of the French police. Born in Morocco, Godard was an officer from 1997 to 2014 . Today he is frequently consulted as a public intellectual on the topic of Islam in France.
} 
impunity as a means of showcasing both their Islamic credentials and their lack of concern about repercussions from civil authorities. ${ }^{57}$ It stands to reason that the absence of the broadcast adhan may be read as symbolic performance of ideology as well. Whether understood as purely defensive or as a mode of strategic resistance, the agentive limits of silence come to the fore in that this particular mode of public engagement does not seem to allow French Muslims to influence the texture of common sense. ${ }^{58}$

Even when it is not broadcast externally via loudspeaker, as in France, the adhan itself is still performed inside mosque walls. According to my Muslim interlocutors in Puy, the call to prayer constitutes a communal obligation for the congregation, meaning that if one member performs the adhan on behalf of the community, then the obligation to God is considered fulfilled. Failure to perform the adhan without a valid excuse constitutes a sin from a doctrinal perspective. ${ }^{59}$ As such, it represents an essential element of faith; the adhan is not optional. With this in mind, the Puy mosque's choice not to request formal permission, and to revert to calling the adhan within mosque walls, suggests both a certain compromise of formal ritual, and further strategic benefits of silence. By attempting to negotiate the public broadcast of the adhan without involving city officials, the Muslim Association of Puy avoided being formally rejected. This goes beyond questions of ego or status to gesture toward the domain of agency: by not pursuing a formal petition, the mosque maintained control over when it might make use of the loudspeaker without formally breaking the law. ${ }^{60}$ It also retains control of the signification of the adhan, which risks morphing or evolving in directions that the Muslims of Puy disagree with if interpreted within a juridical domain or exposed to public debate. ${ }^{61}$ Choosing silence strategically allows for flexibility and case-by-case decision-making. ${ }^{62}$

\footnotetext{
57 Godard also claimed that these mosques, which he characterized as Salafi, sent representatives knocking on doors to pressure people to come to prayer. Interview with the author, February 19, 2018.

58 I am grateful to an anonymous reviewer for this point.

59 Multiple interviews with representatives and members of the Mosquée al Rahman in Le Puy-en-Velay. February 2018. My interlocutors identified the ritual of the adhan as falling into the Islamic category of "sunnah muaqqadah." This category of acts, while often performed as "best practices" are not strictly speaking obligatory in Islamic doctrine. Yet respondents in Puy were adamant about the obligatory and collective nature of the adhan, treating it as "fard al-kifayah," even while they did not identify it as such by name. The Oxford Dictionary of Islam defines fard al-kifaya as a "legal obligation that much be discharged by the Muslim community as a whole." See The Oxford Dictionary of Islam, http://www.oxfor dislamicstudies.com/article/opr/t125/e625. The obligatory nature of the adhan in Islamic doctrine may vary depending on the school of Islamic law that is followed.

60 Alisa Perkins, writing in an American context, argues that civic debate over the adhan in Hamtrack, Michigan, produced this effect. Although the city voted in favor of the Al-Islah Mosque's right to call the adhan over a loudspeaker, classing it, in the process, as protected religious sound, Hamtrack's Municipal Ordinance No 503 also gave the city unprecedented power to determine what counted as "reasonable noise" as well as the power to prohibit the adhan altogether, which had not existed as a legal possibility in the USA prior to this 2004 ruling. See Perkins (2015): 173-174.

${ }^{61}$ Isaac A. Weiner, for example, shows how adhan public debate in Hamtrack, Michigan, served to flatten religious difference and efface signification. See Weiner (2014): 1049-1078.

62 A similar point is made by Guillaume Xavier and Elisabeth Schweiger in "Silence as Doing." The coauthors write "the silence of powerful actors can produce ambiguous understandings of policies, norms, or laws which allows certain actors more room to navigate in the future." See Xavier and Schweiger (2018): 102.
} 
Silence represents another, perhaps less familiar, strategy by which Muslims negotiate belonging in France, alongside unveiling (Fadil 2011), the assiduous separation of culture and religion (Jouili 2019), the drawing of symbolic boundaries around Muslim religiosity (Beaman 2016), and informal negotiations of everyday life (Dessing et al. 2016; Selby et al. 2018). Adopting public silence strategically demands an intimate grasp of sensory norms structuring public engagement. Understanding how common sense qua judgement based on shared sensory perception operates across these tactics of belonging and identity would help illuminate choices and courses of action available to minority groups.

Scholars have pointed out the postcolonial state's concern with defining Islam in such a way as to render it subservient to the State; as long as the adhan remains silent, and thus outside of national debate, it "belongs" to the communities who perform it, precisely in ways that Church bells have ceased to do. ${ }^{63}$ Its public silence, then, performs two simultaneous functions-preventing State co optation and control of the adhan's religious significance, however defined, and enacting a public adherence to Republican norms while simultaneously maintaining external, extraand trans-national, influences in private. ${ }^{64}$ The "gap" in State regulation of the adhan is somewhat ironic, given that the French state has at different times gone out of its way to privilege Islam in order to surveille it and maintain control over its propagation. ${ }^{65}$ Attending to common sense as a political actant helps explain this irony, even as it uncovers naturalized hegemonic norms that structure citizenship and deepens understandings of French republicanism.

The choice not to call the adhan in public has further political implications. Widespread disapproval of the adhan among non-Muslim French lends political leverage to mosque officials in various ways. Specifically, the issue of the public broadcast of the adhan becomes a bargaining chip in early-stage mosque-municipal negotiations over construction permissions, in which Muslim leaders extract concessions in exchange for guaranteeing the future mosque's silence. Slimane Nadour, the Director of Communications at the Grand Mosque of Paris, hinted at this latent power to play on the French majority's fears when he said, "we have a minaret that is 33 meters tall. If we wanted to, we could blast the adhan all the way to Notre

\footnotetext{
${ }^{63}$ Even outside of the state's hand, the signification of the adhan is never fixed. In fact, its public silence may contribute to the production of new valences around the sound; in its absence, French Muslims must rely on alternative mechanisms for remembering prayer times. Many of the Puy congregation had downloaded an adhan app to their mobile phone in order to get customized reminders. Others relied on the Internet or radio, with its concomitant profusion of choice. Faithful can select to hear the adhan performed by Saudis, Turks, Moroccans-each with a unique style, religious orientation, and set of references. Adhan recordings, at the end of the day, are a global industry. Still others gave up trying to maintain the rhythm, "saving" their daytime prayers until their return home, whereupon they completed them back-to-back in order to fulfill their religious obligation within the private sphere of the home.

64 I do not propose that maintaining alternative influences in private is in any way specific to Islam; the same might be said for Catholics or anyone else worshiping privately.

65 Consider, for example the special attention French administrators gave Islamic orders in colonial Algeria. Attempts to "control" Islam continue in France today, manifest in the recent creation of Muslim Councils, the carefully managed importation of foreign imams, and the regulation and taxation of halal businesses the regulation and taxation of halal businesses.
} 
Dame."66 He quickly added that the decision not to call the prayer via loudspeaker represents an unspoken "modus vivendi" for Muslims in France, and that mosque leaders had no intention of taking this action. Thus, silence acts as a public performance of Republican values. Milton Viorst, covering Islam in France in 1994, wrote that in the lead-up to the construction of the "Cathedral Mosque" in Lyon, "construction began only after a decade of legal wrangling, during which Lyon's Muslims agreed to shorten the minaret and suppress the muezzin's traditional call to prayer five times daily." ${ }^{67}$ More recently, in connection with planning for the new Eyyub Sultan Grande Mosquée de Strasbourg (which ceremonially laid a foundation stone to mark the start of construction on October 15, 2017), the issue of the call to prayer came up after city hall opened the project to public scrutiny and gave residents the opportunity to provide feedback directly to the mayor. In response to concerns, city officials requested a clause guaranteeing that the adhan would be limited to the interior of the mosque. ${ }^{68}$ Once written into contracts with the city, any future decision the mosque congregation makes about broadcasting the adhan is contractually constrained, turning the call to prayer into something that would have to be negotiated in court, rather than an expression of religious belief protected by Article 27 of the 1905 law.

\section{Conclusion}

The foregoing sections have centered on religious sound in public space as an inroad to analyzing sense-based collective judgements, grounded in the perception of the urban surround, that feed mainstream ideas of what it means to be French. Examining common sense understandings of "appropriate" sounds in public space within a framework of laïcité reveals several things about the politics of Muslim belonging in France, even as it attunes us to ways in which common sense operates to alter legal frameworks intended to ensure equal rights. First, while the nation observes the 1905 law that protects religious sound (under the aegis of bell ringing), municipalities retain control over the regulation of sound in their territory, such that the law may accommodate local preference. Public opinion in France, however, remains staunchly opposed to the open-air broadcast of the Islamic call to prayer on grounds that include noise concerns, the principled defense of secular space, xenophobia, tradition, and other subjective factors. The technocratic regulation of the adhan as "noise" under loudspeaker laws, coupled with public opposition (or at best indifference), creates a scenario in which municipal power brokers thwart the intention of the national principle protecting the expression of religious conviction, as well as the mandate to treat recognized religions equally under the law. Common sense understandings of tranquilité mute political debate on issues related to citizenship

\footnotetext{
66 Interview with the author. February 23, 2018.

67 Milton Viorst, "The Muslims of France, "Foreign Affairs (September/October 1996): 81.

68 Interview with the author, Rassemblement Annuel des Musulmans de France, Le Bourget, March 31, 2018 .
} 
and belonging of French Muslims and equal rights to public space, transforming these into local-level, "trivial" questions of noise pollution.

Second, we see the French Muslim decision to refrain from broadcasting the adhan as a strategic move that protects their community from negative attention. It also acts to retain control over the significance of the adhan itself, sheltering it from alternative interpretations and associations. Further, preserving the adhan as a sound heard exclusively inside the private space of the mosque enables it to continue to enact most (though not all) of its functions, organizing temporality and spirituality, and physically positioning Mecca as the symbolic heart of the Muslim polity, even as French Muslims perform Republican norms in public.

Third, majority opposition to the sound imbues it with political weight, allowing Muslim leaders to leverage the promise of future silence as a bargaining chip in negotiations with the city. Godard considers that the public broadcast of the adhan would be even more incendiary than the veil or burka in French popular opinion, because veiling is a personal choice with individual consequences, whereas the calling of the adhan represents a communal, collective act. ${ }^{69}$ The broadcast of the adhan from French mosques would be considered highly provocative, he said, adding "if a conglomeration of mosques got together to ask for permission then France might have a serious problem on her hands. ${ }^{70}$ Godard suggested scholars should understand French Muslim voluntary suppression of the public adhan as an example of the community's concessions toward living in Europe. Yet French Muslim approaches to the issue of the adhan reveal strategies predicated on an understanding that their community is excluded. On this issue, French Muslims are not operating as full citizens with equal claims, but rather retrenching and protecting themselves.

Finally, mainstream French conceptions of "silence," it is revealed, incorporate ringing church bells. Put differently, many Catholics and secular French have stopped hearing Church bells; or, if they do hear them, mechanically-speaking, the bells no longer contain sufficient semiotic significance to draw attention to themselves. This common sense understanding of silence enables a cognitive dissonance with political ramifications. It makes it possible for advocates of bells to claim rights under the 1905 law, even as it allows people opposed to noise pollution to claim the right to "tranquilité." This cognitive frame, in which bells are not considered an interruption of silence, enables broad coalitions of the political Right and Christian conservatives, as well as the atheist, secular Left, thereby affectively unifying nonMuslim French in opposition to the adhan. Thus, embodied knowledges inherent in common sense constitutes shared ground that may help explain the sometimes odd political alliances that have formed in recent years. These common sense understandings are triggered when political actors cite bodily, visceral events in political debates, relying on these to generate affective "shortcuts" that reference mainstream

\footnotetext{
69 Interview with the author. February 19, 2018.

70 Interview with the author. February 19, 2018. From a legal standpoint, the issue would be further complicated by the precedent for calling the adhan in the French Departments of Reunion, Mayotte, and during the colonial period, Algeria. In Mayotte, which boasts France's oldest mosque, the adhan has been called since 1905. For more detail, see Idriss Issa, "Les Musulmans réunnionnais voudraient “exporter" leur modèle en métropole," Agence France Presse, April 14, 2003.
} 
norms for their listening audience. In contrast, this normalized silence does not allow space for Islamic sound. When the adhan is characterized as religious, it is excluded from public space on the grounds of the same 1905 laïc formulation that protects the state from religion yet allows religious expression which does not interrupt tranquilité. Alternately, the adhan is categorized simply as "noise," at which point it may be prevented on the basis of local environmental and loudspeaker laws. Both formulations do violence to the full participation of French Muslims in society.

Common sense understandings of silence transforms laïcité into an empty signifier that may be harnessed in the service of opposing political platforms, even as it erodes distinctions between culture and religion. ${ }^{71}$ In the context of local politics surrounding the adhan throughout much of France, laïcité is evoked not in service of a secular project-freedom from religion in public space (in which case it would censor all religious sound including bells)_but as a means of protecting the traditional auditory fabric of Frenchness delimited by municipalities. Thus, this case study demonstrates how culturally entrained listening practices and habitual engagement with the sounded public environment alters the meaning of pacts and laws that constitute foundational principles of state projects. It situates embodied knowledge and common sense as critical, agentive, forces in contemporary political debates.

Acknowledgements I am deeply indebted to the insights of Amélie Barras, Jennifer Fredette, Peter Hall, Jonathan Laurence, Todd Shepard, Lisa Wedeen, and the members of the APSA 2019 "What's Next in Scholarship on France" Workshop, as well as to two anonymous reviewers. I also wish to express great thanks to Mohamed Allouchi, Karine Tavernier, and Giovanni Ponturo, who offered invaluable support and guidance in Le Puy-en-Velay. All mistakes remain my own.

Funding Open access funding provided by University of Basel.

Open Access This article is licensed under a Creative Commons Attribution 4.0 International License, which permits use, sharing, adaptation, distribution and reproduction in any medium or format, as long as you give appropriate credit to the original author(s) and the source, provide a link to the Creative Commons licence, and indicate if changes were made. The images or other third party material in this article are included in the article's Creative Commons licence, unless indicated otherwise in a credit line to the material. If material is not included in the article's Creative Commons licence and your intended use is not permitted by statutory regulation or exceeds the permitted use, you will need to obtain permission directly from the copyright holder. To view a copy of this licence, visit http://creativecommons.org/licen ses/by/4.0/.

\section{References}

Ahearne, J. 2014. Laïcité: a parallel French cultural policy (2002-2007). French Cultural Studies 25(3/4): 320-329.

Akan, M. 2017. Diversité: Challenging or Constituting Laïcité? French Cultural Studies 28(1): $123-137$.

Analyse: Les Minarets en France de Tours Rares et Silencieuses. Le Point, November 30, 2009. http:// www.lepoint.fr/actualites-societe/2009-11-30/analyse-les-minarets-en-france-des-tours-rares-etsilencieuses/920/0/400007.

\footnotetext{
71 I have avoided offering a formal definition of laïcité, in part because this article provides evidence for the ongoing evolution, and co-optation, of the meaning of laïcité. See Bowen (2010): 2 on laïcité as an "essentially contested concept."
} 
Article 27 of the 9 December 1905 law of the French Constitution. https://www.legifrance.gouv.fr/affic hTexte.do?cidTexte=JORFTEXT000000508749\#LEGIARTI000027973675.

Barras, A. 2013. Sacred Laïcité and the Politics of Religious Resurgence in France: Whither Religious Pluralism? Mediterranean Politics 18(2): 276-293.

Barras, A., J. Selby, and L. Beaman. 2016. In/Visible Religion in Public Institutions: Canadian Muslim Public Servants. In Religion and the Exercise of Public Authority, ed. B. Berger and R. Moon, 95-110. Oxford: Hart Publishing.

Baubérot, J. 2012. French secularism: Republican, Indivisible, Democratic, and Social. Cités 4(52): 11-20.

Beaman, J. 2016. As French as Anyone Else: Islam and the North African Second Generation in France. International Migration Review 50(1): 41-69.

Beaman, L. 2008. A Cross-National Comparison of Approaches to Religious Diversity: Canada, France and the United States. In Religion and diversity in Canada, ed. L. Beaman and P. Beyer. Leiden: Brill.

Beaman, L. 2020. The Transition of Religion to Culture in Law and Public Discourse. New York: Routledge.

Berger, B. and R. Moon, eds. 2016. Religion and the Exercise of Public Authority, Hart Publishing.

Bowen, J. 2010. Why the French Don't Like Headscarves: Islam, the state, and public space. Princeton: Princeton University Press.

Corbin, A. 1998. Village bells: Sound and meaning in 19th century french countryside. Translated by Thomas Martin. New York: Columbia University Press.

Court of Appeal, Fourth Appellate District Division One, State of California, Stephen Sedlock et al v. Timothy Baird et al. Super. Ct. No. 37-2013-00035910-CU-MC-CTL.

Davidson, N. 2012. Only Muslim: Embodying islam in twentieth century France. Ithaca: Cornell University Press.

Dessing, N., N. Jeldtoft, J. Nielsen, and L. Woodhead (eds.). 2016. Everyday lived Islam in Europe. London: Routledge.

European Commission's Environmental Noise Directive 2002/49/EC. https://ec.europa.eu/environment/ noise/directive_en.htm.

European Court of Human Rights, Case of Lautsi and Others v. Italy, Judgment, March 18, 2011.

European Court of Human Rights, Case of Dahlab v. Switzerland, Judgment, February 15, 2001. https:// www.servat.unibe.ch/dfr/em423939.html.

Farabet, R. 2001. "From One Head to Another". In Experimental sound and radio, ed. A. Weiss, 55-57. Cambridge: MIT Press.

Fadil, N. 2011. not-/unveiling as an ethical practice. Feminist Review 98: 83-109.

Ferguson, K. 2003. Silence: a politics. Contemporary Political Theory 2: 49-65.

Fernando, M. 2014. The Republic Unsettled: Muslim French and the contradictions of secularism. Durham: Duke University Press.

Foucault, M. 1980. Power/knowledge: Selected interviews and other writings 1972-1977, ed. C. Gordon. New York: Pantheon Books.

"France jusqu'a 30 mois de prison pour des jeunes ayant fait croire a un attentat dans un train." Agence France Presse Infos Mondiales, Europresse, BnF, December 9, 2015.

Fredette, J. 2014. Constructing muslims in France: Discourse, public identity, and the politics of citizenship. Philadelphia: Temple University Press.

Friedman, H. 2016. Israel Court Says Shouting Allahu Akbar Can Amount to a Breach of Peace. Religious Clause, July 5, 2016.

Fujii, L.A. 2018. Interviewing in social science research: a relational approach. New York: Routledge.

Gaudichet, N. 2010. Immigration: Sarkozy inflexible sur le fond. Agence France Presse, Europresse, BnF, November 17, 2010.

Göle, N. 2002. Islam in public: New visibilities and new imaginaries. Public Culture 14(1): 173-190.

Gros de Larquier, S. 2009. ANALYSE-Les minarets en France, des tours rares et silencieuses Le Point, Europresse, BnF, November 20, 2009. Modified December 1, 2009.

Guillaume, X., and E. Schweiger. 2018. Silence as Doing. In Political silence: Meanings, functions, and ambiguity, ed. S. Dingli and T. Cooke, 96-111. New York: Routledge.

Gumbel, P. 2013. France's got talent: The woeful consequences of French elitism. Kindle Edition.

Hackett, C. 2017. Five Facts About the Muslim Population in Europe. Pew Research November 29, 2017. https://www.pewresearch.org/fact-tank/2017/11/29/5-facts-about-the-muslim-population-in-europe/. 
Horaires. Official Website of the Cathédral du Puy. https://www.cathedraledupuy.org/vie-de-la-cathe drale/horaires-messes-et-offices/horaire-des-messes.

Hopf, T. 2013. Common-sense in constructivism and hegemony in world politics. International Organization 67(2): 317-354.

Issa, I. 2003. Les Musulmans réunionnais voudraient "exporter" leur modèle en métropole, Agence France Presse.

Jonker, G., and V. Amiraux (eds.). 2006. Politics of visibility: Young muslims in European public spaces. Bielefeld: Transcript Verlag.

Jouili, J. 2015. Pious practice and secular constraints: Women in the islamic revival in Europe. Stanford: Stanford University Press.

Jouili, J. 2019. "Islam and culture: Dis/junctures in a modern conceptual Terrain. Comparative Studies in Society and History 61(1): 207-237.

Jouili, J., and A. Moors. 2014. Introduction: Islamic sounds and the politics of listening. Anthropological Quarterly 87(4): 977-988.

Kaplan, D. 2011. Beyond expulsion: Jews, christians, and reformation Strasbourg. Stanford: Stanford University Press.

Kastoryano, R. and A. Escafré-Dublet. 2016. Identity, culture, and politics: the other and the self in France, in The Oxford Handbook of French Politics. R. Elgie, E. Grossman, and A. Mazur, eds. Oxford: Oxford University Press, 2016.

Kepel, G. 1991. Les banlieues de l'islam: Naissance d'une religion en France. Paris: Editions du Seuil.

Khoja-Moolji, S. 2016. The sounds of racialized masculinities: Examining the affective pedagogies of Allahu Akbar. Feminist Media Studies 16(6): 1110-1113.

Killian, C. 2007. From a community of believers to an islam of the heart: 'Conspicuous' symbols, muslim practices, and the privatization of religion in France. Sociology of Religion 68(3): 305-320.

La France et l'Islam: Les resultats du sondage de l'IFOP la Religion et la Loi. Le Monde, Europresse, BnF, October 13, 1994.

La population a gagné 3.028 habitants. l'Eveil de la Haute Loire, January 2, 2018. https://www.leveil.fr/ puy-en-velay/economie/haute-loire/2018/01/02/la-population-a-gagne-3-028-habitants_12687147. html.

Langlois, B. 2011. Debat sur la laicite: les musulmans en ont marre d'etre les bouc emissaires. Agence France Presse, Europresse, BnF, March 20, 2011.

Latour, B. 2005. Reassembling the social: an introduction to actor network theory. Oxford: Oxford University Press.

Laurent, S. 2015. Interdire les prêches en arabe? Le PS reliance une idée que l'UMP jugeait inapplicable. Le Monde.fr, November 11, 2015. http://www.lemonde.fr/les-decodeurs/article/2015/11/23/inter dire-les-preches-en-arabe-le-ps-relance-une-idee-que-l-ump-jugeait-inapplicable_4815768_43557 70.html.

Leonidas. 2011. L'appel à la prière retentit au Puy-en-Velay, avec la benediction de Laurent Wauquiez. Riposte Laique, June 3, 2011. https://ripostelaique.com/lappel-a-la-priere-retentit-au-puy-en-velay -avec-la-benediction-de-laurent-wauquiez.html.

L'imam Abdelali Mamoun Accuse les Cloches d'eglises de sonner. Les Observateurs, August 19, 2016. https://lesobservateurs.ch/2016/08/19/france-limam-abdelali-mamoun-accuse-cloches-eglises-desonner/.

Nilsson, P. 2019. French populism and discourse on secularism. London: Bloomsbury Academic.

Perkins, A. 2015. Muslim sound, public space, and citizenship agendas in an American City. Citizenship Studies 19(2): 169-183.

Scott, J. 1985. Weapons of the weak: Everyday forms of peasant resistance. New Haven: Yale University Press.

Scott, J.W. 2007. The politics of the veil. Princeton: Princeton University Press.

Segurane, C. 2011. France: du Minaret à l'appel à la prière, AgoraVox: Le Média Citoyen, August 16, 2011. https://www.agoravox.fr/actualites/religions/article/france-du-minaret-a-1-appel-a-la-99011.

Selby, J. 2012. Questioning french secularism: Gender politics and islam in a Parisian Suburb. New York: Palgrave MacMillan.

Selby, J., Barras, A. and Beaman, L. 2018. Beyond accommodation: Everyday narratives of muslim Canadians. Vancouver: University of British Columbia Press.

Simas, E., S. Clifford, and J. Kirkland. 2020. How empathic concern fuels political polarization. American Political Science Review 114(1): 258-269. 
Sole, R., and H. Tincq. 1989. Le rejet de l'Islam et l'attrait de la Freance Selon un sondage IFOP, plus de deux Francais sur trois ont une image très negative de l'Islam et neuf musulmans sur dix jugent leur religion compatible avec l'integration. Le Monde: Europresse, BnF.

Stockemer, D. 2014. Who are the members of the French National Front? Evidence from interview research. French Politics 12: 36-58.

Suleiman, E. 1978. Elites in French society: The politics of survival. Princeton: Princeton University Press.

Tchumkam, H. 2019. Banlieue sounds, or, the right to exist. In Remapping sound studies, ed. G. Steingo and J. Sykes, 185-202. Durham: Duke University Press.

Thiolay, Boris. 2010. Un imam trop républicain? L'Express, Europresse, BnF, March 18, 2010.

Tête, E. 1997. Territoire et sonorities campanaires. In Art campanaire en Nord-Pas-de-Calais: ouvrage collectif, ed. P. Hébérle. Lille: Domaines Musiques.

Thomas, E. 2011. Immigration, Islam, and the politics of belonging in France: a comparative framework. Philadelphia: University of Pennsylvania Press.

Thompson, Y. Islam: Comment peut-on financer les mosques de France? franceinfo, August 3, 2016. https://www.francetvinfo.fr/societe/religion/laicite/islam-comment-peut-on-financer-les-mosqueesde-france_1573803.html.

Vallette, C. 2009. Les Minarets en France une affaire municipal, Agence France Press, Europresse, BnF.

Viorst, M. 1996. The Muslims of France. Foreign Affairs, September/October 1996.

Weiner, I.A. 2014. Calling everyone to pray: Pluralism, secularism, and the adhān in hamtrack, michigan. Anthropological Quarterly 87(4): 1049-1077.

Publisher's Note Springer Nature remains neutral with regard to jurisdictional claims in published maps and institutional affiliations. 